\title{
ROOTING AND ACCLIMATIZATION OF THE JAPANESE PLUM TREE, CV. AMÉRICA ${ }^{1}$
}

\author{
JULIANA DE MAGALHÃES BANDEIRA², LIANE BAHR THUROW ${ }^{3}$, \\ EUGENIA JACIRA BOLACEL BRAGA ${ }^{4}$, JOSÉ ANTONIO PETERS ${ }^{4}$, VALMOR JOÃO BIANCHI ${ }^{4}$
}

ABSTRACT - Rooting and acclimatization are limiting steps in plant micropropagation, especially in woody plant species. This study aimed to evaluate the IAA and IBA effect on the in vitro rooting and acclimatization of micropropagated shoots of Japanese plum (Prunus salicina Lindl.) cv. América. Shoots from 3 to $4 \mathrm{~cm}$ long were inoculated in MS medium with half salt and vitamin concentrations (MS/2) added with IAA and IBA $\left(0,0.25,0.5,0.75\right.$ and $\left.1 \mathrm{mg} \mathrm{L}^{-1}\right)$. After a 20-day period in in vitro cultivation, the shoots were evaluated, and then transferred to a greenhouse, and evaluated after 30 days. At the end of the in vitro cultivation period, no significant interactions were observed for number of roots per shoot and rooting percentage, but a significant effect was recorded for auxin type only, for which shoots grown in media added with IBA showed high values -0.87 and $41.95 \%$, respectively. A linear increase response from 1.45 to $5.75 \mathrm{~cm}$ was verified for root length of shoots cultivated in IBA medium; however, no significant effect was observed, and a $0.86 \mathrm{~cm}$ average root length per shoot grown in medium added with IAA was found. After 30 days of acclimatization period, the largest survival percentage was obtained from shoots cultivated in medium with $1 \mathrm{mg} \mathrm{L}^{-1}$ of IBA and IAA ( $88 \%$ and 92\%, respectively). Although, IBA provided the highest in vitro rooting, most of the surviving shoots were those originated in IAA-added medium, probably because IBA promoted longer fibrous roots, less appropriate for transplant and soil fixation, as they are easily damaged. It was concluded that in vitro rooting with the addition of the highest IAA concentration $\left(1 \mathrm{mg} \mathrm{L}^{-1}\right)$ provided the greatest plant survival during the acclimatization period of the Japanese plum cv. América.

Index terms: Prunus salicina, micropropagation, auxins.

\section{ENRAIZAMENTO E ACLIMATIZAČ̃̃O DE AMEIXEIRA-JAPONESA, CV. AMÉRICA}

RESUMO - O enraizamento e a aclimatização são etapas limitantes da micropropagação de plantas, principalmente de espécies frutíferas lenhosas. Este trabalho teve o objetivo de avaliar o efeito do AIA e do AIB sobre o enraizamento in vitro e aclimatização de brotações micropropagadas de ameixeira-japonesa (Prunus salicina Lindl.) cv. América. Brotações de $3 \mathrm{a} 4 \mathrm{~cm}$ de comprimento foram inoculadas em meio MS contendo metade da concentração dos sais e vitaminas (MS/2) e suplementado com AIA ou AIB, nas concentrações de $0 ; 0,25 ; 0,5 ; 0,75 \mathrm{e} 1 \mathrm{mg} \mathrm{L}^{-1}$. Após 20 dias de cultivo in vitro, as brotações foram avaliadas e transferidas para casa de vegetação, sendo novamente avaliadas após 30 dias. Ao final do período de cultivo in vitro, não foi observada interação significativa para o número de raízes por brotação e percentagem de enraizamento, sendo verificado efeito significativo para o tipo de auxina, onde brotações cultivadas em meio acrescido de AIB demonstraram maiores valores de 0,87 e $41,95 \%$, respectivamente. Foi verificado aumento linear variando de 1,45 a 5,73 cm para o comprimento das raízes das brotações cultivadas no meio com AIB. Após 30 dias de aclimatização, a maior percentagem de sobrevivência ocorreu nas brotações cultivadas em meio com $1 \mathrm{mg} \mathrm{L}^{-1}$ de AIB e AIA ( $88 \%$ e 92\%, respectivamente). Embora o AIB tenha proporcionado maior enraizamento in vitro, a maioria das brotações sobreviventes foram aquelas provenientes do meio contendo AIA, provavelmente devido ao AIB ter promovido raízes mais longas e fibrosas, as quais são menos adequadas para o transplantio e pegamento, pois são facilmente danificadas. Conclui-se que o enraizamento in vitro com a adição da maior concentração de $\operatorname{AIA}\left(1 \mathrm{mg} \mathrm{L}^{-1}\right)$ proporciona maior sobrevivência das plantas durante a aclimatização de ameixeira-japonesa cv. América.

Termos para indexação: Prunus salicina, micropropagação, auxinas.

\footnotetext{
'(Trabalho 149-11). Recebido em: 13-05-2011. Aceito para publicação em: 29-03-2012. Study developed at the Plant Tissue Culture Laboratory of the Federal University of Pelotas (UFPel).

${ }^{2}$ Doctor in Agronomy - Fruitculture of Temperate Climate - E-mail: bandeira_jm@hotmail.com

${ }^{3}$ Agronomy graduate student. E-mail: lianepel@yahoo.com.br

${ }^{4}$ Botany Department Professor, Biology Institute of the Federal University of Pelotas (UFPel), PO Box 354, 96010-900, Capão do Leão, Rio Grande do Sul, Brazil.E-mails: jacirabraga@hotmail.com, japeters1@hotmail.com, valmorjb@yahoo.com
} 


\section{INTRODUCTION}

Brazil is the third largest fruit producer in the world, but the country still imports large quantities of temperate fruit, especially plums and pears (REETZ, 2007). Due to more favorable climate, the Japanese plum ( $P$. salicina Lindl.) is grown mainly in the States of Rio Grande do Sul and Santa Catarina (CASTRO, 2003) and the cv. América is one of the preferred to cultivation because of its organoleptic characteristics and adaptation to local conditions (REVERS; MACHADO, 2005). The Japanese plum tree propagation in Brazil is done mainly by active bud grafting on peach rootstocks (NACHTIGAL; PEREIRA, 2000), which limits the orchard's longevity. Thus, the use of plum rootstocks or self-rooted cultivars (MINDÊLLO-NETO, 2005; TONIETTO et al., 2005), obtained by a method which enables the preservation of the genetic and sanitary quality of the plant, together with a better orchard management, can significantly contribute to a higher orchard production efficacy and longevity. In vitro cultivation has been considered a potentially viable alternative to woody species large-scale cloning and commercial plant production, which allows controlling several variables that are responsible for plant development (GUTIÉRREZ et al., 2011), thus enabling the multiplication of disease-free plants in the short run, regardless of the season (VIGANÓ et al., 2007).

One of the crucial steps in in vitro cultivation is rooting, which is genetically determined, but also influenced by culture environment factors. These conditions can limit the creation of general protocols for species of the Prunus genus (ROGALSKI et al., 2003b; HAZARIKA, 2006). The factors that most influence success in this process are mineral concentration in the culture media, generally used in low quantities (SOUZA; PEREIRA, 2007), and auxin type and concentration (HARTMANN et al., 2002). For Prunus genus species rooting, the most commonly used auxins are indole-3-butyric acid (IBA), 1-naphthaleneacetic acid (NAA) and indole3-acetic acid (IAA) (ROCHA et al., 2006).

Another relevant aspect to be considered is acclimatization, once plants from in vitro cultivation are highly sensible to dehydration, as they are not able to keep the water balance in an ex vitro condition, and this happens because in vitro cultivation provides a controlled microclimate with high humidity and low photon flow density levels (HAZARIKA, 2006; RESENDE et al., 2010; HORBACH et al., 2011). These special conditions alter the plant morphology, anatomy and physiology (POSPISILOVÁ et al., 2000) and can limit the ex vitro environment acclimatization process.

Thus, the present study aimed to evaluate the IAA and IBA effect on the in vitro rooting and acclimatization of micropropagated shoots of Japanese plum (Prunus salicina Lindl.) cv. América.

\section{MATERIALS AND METHODS}

In an initial step, 3-4 $\mathrm{cm}$ long Japanese plum cv. América shoots from in vitro cultivation were multiplied in MS medium (MURASHIGE; SKOOG, 1962) added with $0.3 \mathrm{mg} \mathrm{L}^{-1}$ of BAP (6-benzylaminopurine) and $1 \mathrm{mg} \mathrm{L}^{-1}$ of $\mathrm{GA}_{3}$ (gibberellic acid) were inoculated in medium containing half $\mathrm{MS}(\mathrm{MS} / 2)$ salt and vitamin concentrations added with $20 \mathrm{~g} \mathrm{~L}^{-1}$ of sucrose, $100 \mathrm{mg} \mathrm{L}^{-1}$ of inositol, and different IAA or IBA concentrations $\left(0,0.25,0.5,0.75\right.$ and $\left.1 \mathrm{mg} \mathrm{L}^{-1}\right)$. The media were solidified with $7 \mathrm{~g} \mathrm{~L}^{-1}$ of agar after $\mathrm{pH}$ adjustment to 5.8.

The explants were kept in a growth room with controlled light and temperature conditions (42 $\mu \mathrm{mol} \mathrm{m} \mathrm{m}^{-2} \mathrm{~s}^{-1}$ of photon flow density, 16 hours of light and $25 \pm 1^{\circ} \mathrm{C}$ ) for 20 days. All plants were then transplanted in to cell polystyrene trays ( 72 cells, $121.2 \mathrm{~cm}^{2}$ per cell) which contained autoclaved substrate $\left[\left(\right.\right.$ Plantmax $^{\circledR}+$ carbonized rice hull $\left.-1: 1(\mathrm{v}: \mathrm{v})\right]$ and kept in an intermittent mist chamber $(90-95 \%$ relative humidity) set inside in a greenhouse, for 20 days. After this period, the trays were transferred to normal greenhouse condition $\left(22-28^{\circ} \mathrm{C}\right.$ at an average $70-80 \%$ relative humidity), for more 10 days, totalizing 30 days of ex vitro experiment.

Upon the end of the in vitro cultivation (20 days), the following estimates were made: rooting percentage, number of roots per shoot, and root length $(\mathrm{cm})$, and 30 days after the plants were transplanted in the greenhouse, the plant survival percentage was estimated to evaluate the plants acclimatization.

The experimental design was entirely randomized and consisted of a $2 \times 5$ factorial with two auxin sources and five different auxin concentrations, and contained five replications which were represented by a flask with five shoots. For the acclimatization phase the same experimental design was adopted. The data obtained were submitted to variance analysis for the mean comparison of auxin type and the regression coefficient factor of the different concentrations, analyzed by means of the Statistical WinStat 2.0 software (MACHADO; CONCEIÇÃO, 2003). 


\section{RESULTS AND DISCUSSION}

In the rooting stage, a significant interaction between factors studied for the number of roots per shoot and rooting percentage was not found; but for this variables there was only an effect for auxin type, the best results were obtained by the media added with IBA (0.87 and $41.95 \%$, respectively - Figure 1a and $1 \mathrm{~b}$ ). IBA positive effect on the in vitro rooting of Prunus species was also demonstrated by Rogalski et al. (2003b) in Capdeboscq, GF677, VP411 and VP417 rootstocks and by Morini et al. (1991) upon studying different Prunus cerasifera clones. IBA also favored a better in vitro apple cv. Fred Hough rooting, as compared to NAA and IAA (CENTELLAS et al., 1999).

Radmann et al. (2002) found that IAA favored the formation of a good rooting system for the apple 'M-9' rootstock, without the formation of thick, fibrous roots and with a higher secondary root formation and a good development of the plants in all concentrations tested (from 0.09 to $17.52 \mathrm{mg} \mathrm{L}^{-1}$ ). The same authors emphasized that rooted shoots, in the presence of IBA and NAA, showed better rooting with lower IAA concentrations, probably due to a higher IAA degradation in the presence of light, as well as to the lower absorption rate in contrast to other auxins reported by Nissen and Sutter (1990), and Centellas et al. (1999); however, it is worthy to mention that the rooting response also depends on intrinsic characteristics of each species and/or cultivar (PATI et al., 2006), and of course, the explant type is very important to promote different rooting responses. In the present study, it was used shoots segments without leaves, while Radmann et al. (2002) tested stem discs without leaves.

A significant interaction between the factors was found for the average root length, which was higher in the culture medium added with IBA for all tested concentrations; from 1.45 to $5.73 \mathrm{~cm}$ a linear increment was verified, at zero and $1 \mathrm{mg} \mathrm{L}^{-1}$ of IBA concentrations, respectively. IAA addition did not have a significant effect, resulting in a lower average root length $(0.86 \mathrm{~cm})$ as compared to IBA (Figure 2).

The shoots cultivated in media that contained IBA originated more elongated plants with a greater number of leaves, and these characteristics became even more prominent as the concentration of this regulator was increased. On the other hand, the shoots grown in medium containing IAA at concentrations higher than $0.75 \mathrm{mg} \mathrm{L}^{-1}$ formed plants that presented a smaller canopy development, with short internodes (Figure 3). According to Mohammed and Vidaver (1990), the rooting system formation (development) is important to plant survival in the ex vitro acclimatization stage, but a good canopy development is also important because it contribute for hormone production - mainly auxins - which affect the root system development and, consequently, make the plant more suited for ex vitro establishment.

According to Leopold and Kriedemann (1975), the reduced rooting induction ability of IAA, a weak auxin (CALDAS et al., 1990), as compared to NAA and IBA, can be attributed to various metabolic mechanisms which reduce or nullify its effects through the conjugation and/or degradation in explant tissues by enzymatic oxidation reactions catalyzed by peroxidases (IAA-oxidase) (GRATTAPAGLIA; MACHADO, 1990). In addition, exogenous IAA presents low stability when applied to the culture medium, and is more easily degraded by light than IBA (NISSEN; SUTTER, 1990). These characteristics can be related to the less intense IAA effect on the variables analyzed in this study.

In view of the fact that most plants are susceptible to dehydration during the acclimatization period, this stage can be a limiting factor for the establishment of micropropagation protocols for some species (HAZARIKA, 2006), restricting plant production (MALDA et al., 1999). In the present study, a higher survival percentage of plants from IAA $(92 \%)$ and IBA (88\%) culture media at the highest concentrations used was found 20 days after the ex vitro condition transfer (Figure 4).

Although IBA favored the formation of a greater number of and longer roots during in vitro rooting, these characteristics, especially root length, may have interfered with acclimatization, once very long roots can be easily damaged during the transplant process (RADMANN et al., 2003). Furthermore, root disruption or breakage facilitates the appearance of infection areas caused by pathogens which can affect plant survival. Conversely, a higher survival percentage showed by plants from IAA medium may be connected to shorter roots formed with the use of this plant growth regulator, which are more easily handled, causing less damage upon transplant.

The IBA generated a more effective rooting than IAA during in vitro cultivation; however, to improve the effectiveness of acclimatization, a shorter in vitro cultivation period should be done, to produce smaller root formation, maybe between 10 to 15 days. After all, according to De Klerk et al. (1997), adventitious root induction occurs in the first five days following transfer to rooting medium. This way, it would be possible to promote the induction and formation of primordial roots only, which are more adequate for plant transplant and establishment, as they are going through an active growth stage, thus 
avoiding breakage upon culture medium removal (GRATTAPAGLIA; MACHADO, 1998) and facilitating the wash and removal of the medium that has adhered to the shoot base, as well as plant transplant into the substrate (ASSIS; TEIXEIRA, 1999).

There are reports of Prunus spp. rootstock shoots submitted to in vitro rooting with IBA addition at concentrations between 0.1 and $0.5 \mathrm{mg} \mathrm{L}^{-1}$ which were able to root and survive when transferred to the substrate during the acclimatization process, even though they did not present an apparent root formation (ROGALSKI et al., 2003a). Pietropaolo and Reisch (1984) also observed the same response in 'Stanley' plum shoot acclimatization that did not show apparent rooting during in vitro cultivation, but nevertheless developed a rooting system, showing a high survival rate and rooting for plants in ex vitro conditions.

The acclimatization process of the Prunus genus has showed good results in a previous treatment with auxin during in vitro rooting, similarly to results found by Radice et al. (1999) with Prunus Mr $\mathrm{S} 2 / 5$ rootstock, in which the use of auxin considerably increased the surviving plant percentage during acclimatization, with a survival index varying from 84 to $93 \%$.
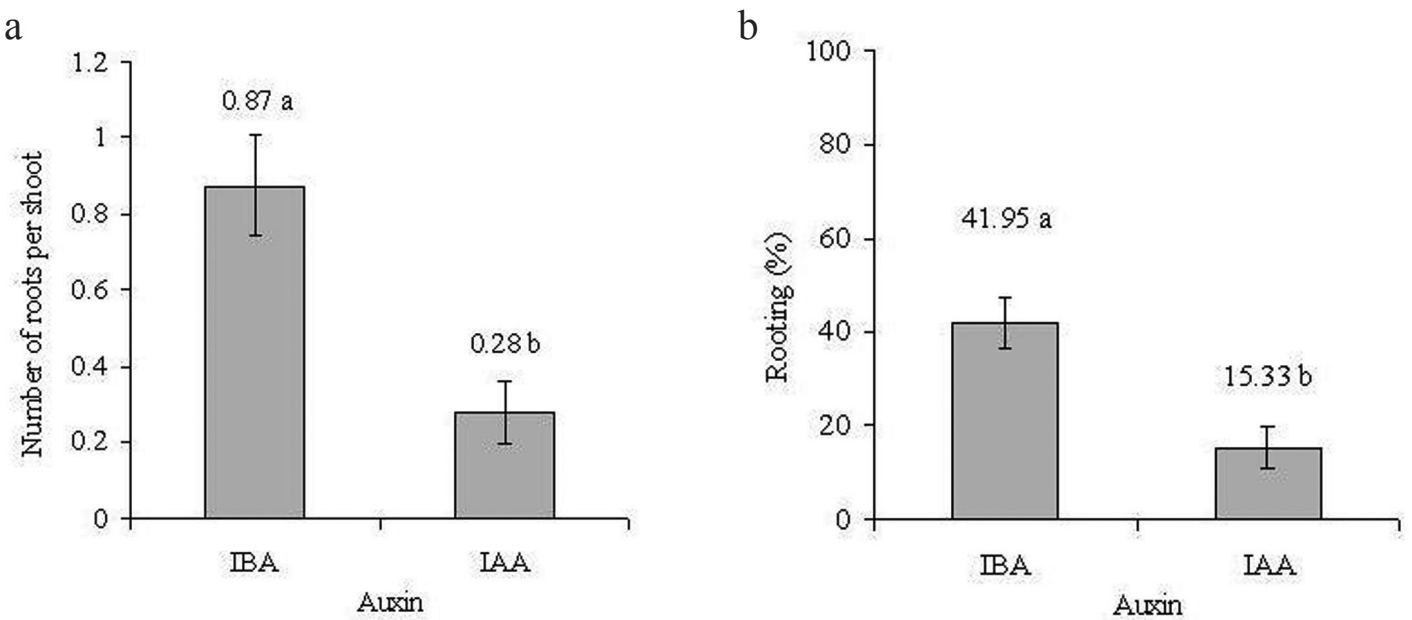

FIGURE 1 - Number of roots per shoot (a) and rooting percentage of Japanese plum (Prunus salicina Lindl.) $\mathrm{cv}$. América shoots at 20 days of in vitro cultivation in MS/2 medium added with different IBA and IAA concentrations $\left(0,0.25,0.50,0.75\right.$ and $\left.1.0 \mathrm{mg} \mathrm{L}^{-1}\right)$. Bars represent standard error of the mean. UFPel, Pelotas/RS, 2011.

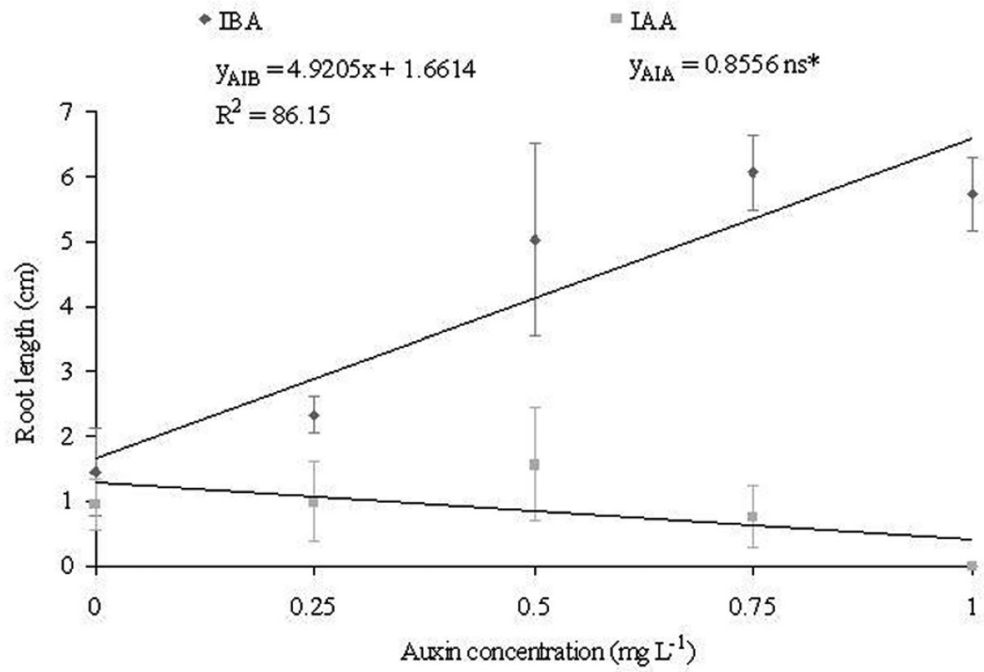

FIGURE 2 - Average root length of Japanese plum (Prunus salicina Lindl.), cv. América, at 20 days of in vitro cultivation in $\mathrm{MS} / 2$ medium added with different IBA and IAA concentrations. Bars represent average error of the mean. $\mathrm{Ns}^{*}$ polynomial regression equation not significant. UFPel, Pelotas/RS, 2011. 


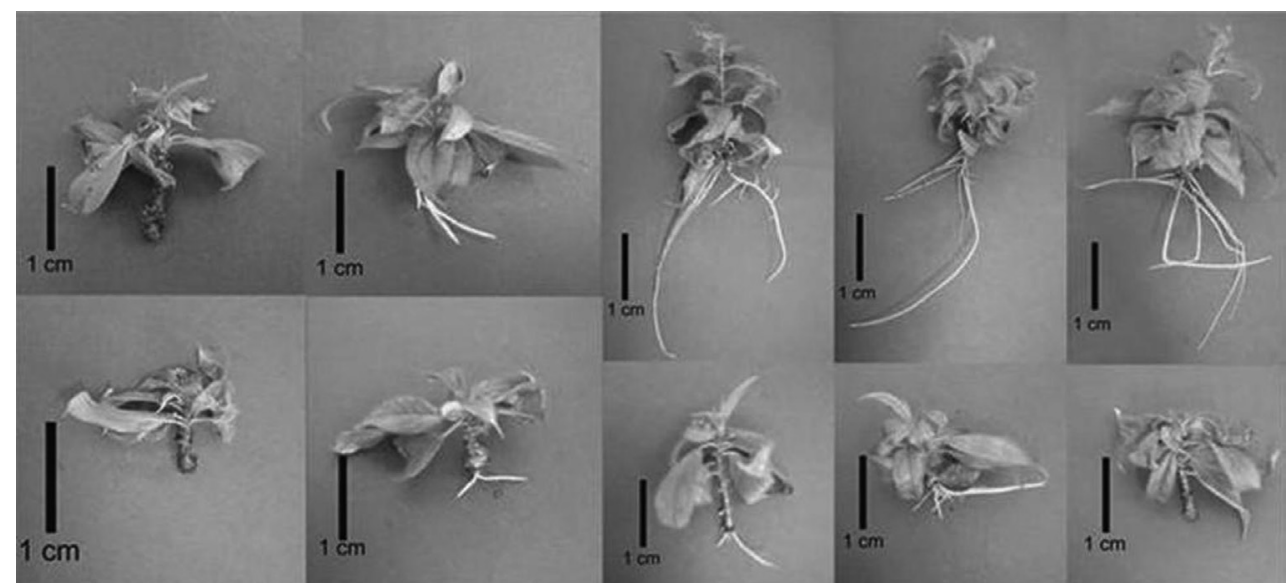

FIGURE 3 - Plants of Japanese plum (Prunus salicina Lindl.) cv. América after 20 days of in vitro cultivation in MS/2 medium added with different IBA $(\mathrm{a}-\mathrm{e})$ and IAA $(\mathrm{f}-\mathrm{j})$ concentrations $(0,0.25$, 0.50, 0.75 and $1.0 \mathrm{mg} \mathrm{L}^{-1}$ ). UFPel, Pelotas/RS, 2011.

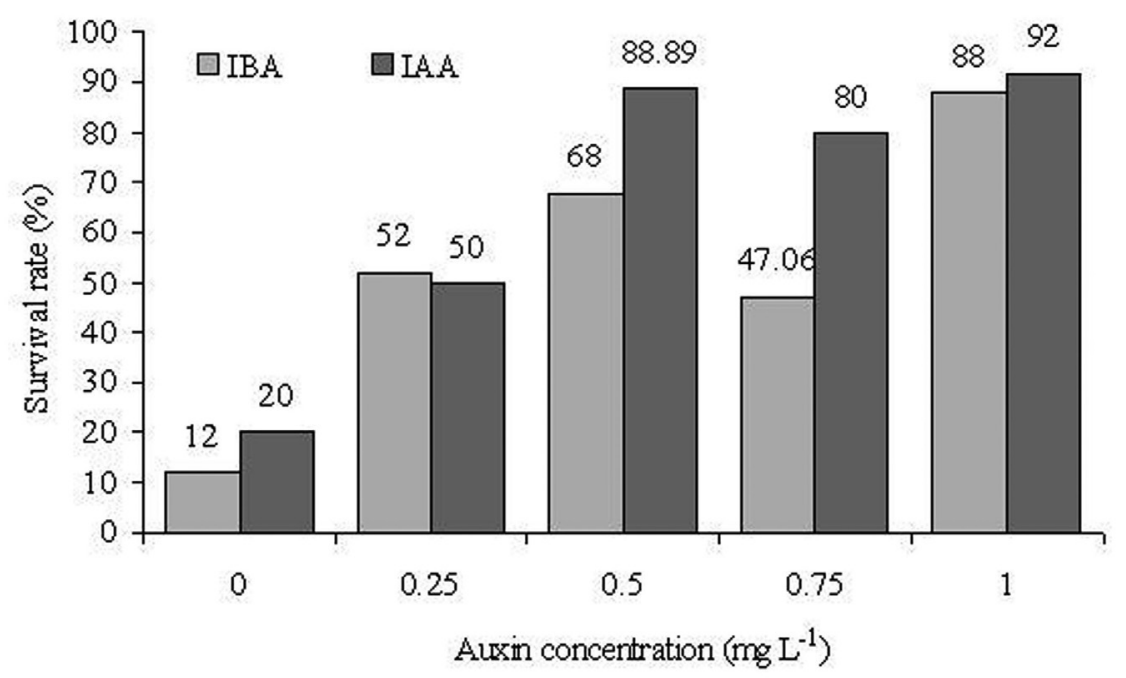

FIGURE 4 - Survival percentage after a 30-day acclimatization period of plants of Japanese plum (Prunus salicina Lindl.) cv. América micropropagated and rooted in vitro in MS/2 medium added with different IAA and IBA concentrations. UFPel, Pelotas/RS, 2011.

\section{CONCLUSIONS}

The growth regulator IBA promoted better and faster rooting process in Japanese plum, cv. América during the in vitro cultivation. However, under the conditions the present study has been developed, IAA provided greater plant survival during the acclimatization period independently of the concentration utilized.

\section{ACKNOWLEDGEMENTS}

The authors gratefully acknowledge the scholarship granted by $\mathrm{CNPq}$, which was fundamental to carry out this research and the CNPq-Universal notice support $n^{\circ} 478954 / 2007 / 7$. 


\section{REFERENCES}

ASSIS, T.F. de; TEIXEIRA, S.L. Enraizamento de plantas lenhosas. In: TORRES, A.C.; CALDAS, L.S.; BUSO, J.A. (Ed.). Cultura de tecidos e transformação genética de plantas. Brasília: Embrapa-SPI/ Embrapa-CNPH, 1999. v.1, p.261-296.

CALDAS, L.S.; HARIDASAN, P.; FERREIRA, M.E. Meios nutritivos. In: TORRES, A.C.; CALDAS, L.S. (Ed.). Técnicas e aplicações da cultura de tecidos de plantas. Brasília: ABCTP/EMBRAPACNPH, 1990. p.37-70.

CASTRO, L.A.S. Ameixa produção. Pelotas: Embrapa-SPI, 2003. 115p.

CENTELLAS, A.Q.; FORTES, G.R. de L.; MÜLLER, N.T.G.; ZANOL, G.C.; FLORES, R.; GOTTINARI, R.A. Efeito de auxinas sintéticas no enraizamento in vitro da macieira. Pesquisa Agropecuária Brasileira, Brasília, v.34, n.2, p.181-186, 1999.

DE KLERK, G.J.; JOLANDA, T.B.; SVETLA, $M$. Effectiveness of indoleacetic acid, indolbutyric acid and napthaleneacetic acid, during adventitious root formation in vitro in Malus Jork 9. Plant Cell, Rockville, v.49, p.39-44, 1997.

GUTIÉRREZ, I.E.M.; NEPOMUCENO, C.F.; LEDO, C.A.S.; SANTANA, J.R.F. Micropropagation and acclimatization of Bauhinia cheilantha (an important medicinal plant). African Journal of Biotechnology, Bowie, v.10, n.8, p.1353-1358, 2011.

GRATTAPAGLIA, D.; MACHADO, M.A. Micropropagação. In: TORRES, A.C.; CALDAS, L.S. Técnicas e aplicações da cultura de tecidos de plantas. Brasília: ABCTP/EMBRAPA-CNPH. 1990. p.99-169.

GRATTAPAGLIA, D.; MACHADO, M.A. Micropropagação. In: TORRES, A.C.; CALDAS, L.S.; BUSO, J.A. Cultura de tecidos e transformação genética de plantas. Brasília: EMBRAPA-SPI/ EMBRAPA-CNPH, 1998. v.2, p.183-260.

HARTMANN, H.T.; KESTER, D.E.; DAVIES JR., F.T.; GENEVE, R.L. Plant propagation: principles and practices. New Jersey: Prentice Hall, 2002.

HAZARIKA, B.N. Morpho-physiological disorders in vitro culture of plants. Scientia Horticulturae, Amsterdam, v.108, p.105-120, 2006.
HORBACH, M.A.; BISOGNIN, D.A.; KIELSE, P.; QUADROS, K.M. de; FICK, T.A. Micropropagação de plântulas de erva-mate obtidas de embriões zigóticos. Ciência Rural, Santa Maria, v.41, n.1, p.113-119, 2011.

LEOPOLD, A.C.; KRIEDEMANN, E.P. Plant growth and development. 2.ed. New York: Mc Graw Hill, 1975.

MACHADO, A.A.; CONCEIÇÃO, A.R. Sistema de análise estatística para Windows. Winstat. Versão 2.0. Pelotas: UFPel, 2003.

MALDA, G.; SUZÁN, H.; BACKHAUS, R. In vitro culture as a potencial method for the conservation of endangered plants possessing crassulacean acid metabolism. Scientia Horticulturae, Amsterdam, v.81, p.71-87, 1999.

MINDÊLLO NETO, U.R. Enraizamento de estacas de pessegueiro em função do uso de ácido indolbutírico e fertilizante orgânico. Revista Brasileira de Fruticultura, Jaboticabal, v.27, n.1, p.92-94, 2005.

MOHAMMED, G.H.; VIDAVER, W.E. The influence of acclimatization treatment and planted morphology $n$ early greenhouse performance of tissue-cultured. Plant Cell Tissue, Holanda, v.21, p.111-117, 1990.

MORINI, S.; LORETI, F.; SCIUTTI, R. Response of some Mr.S. plum clones to in vitro propagation, Acta Horticulturae, Leuven, v.283, p.207-212, 1991

MURASHIGE, T.; SKOOG, F. A revised medium for rapid growth and bioassays with tobacco tissue cultures. Physiologia Plantarum, Copenhagen, v.15, p.473-497, 1962.

NACHTIGAL, J.C.; PEREIRA, F.M. Propagação do pessegueiro (Prunus persica L. Batsch) cv. Okinawa por meio de estacas herbáceas em câmara de nebulização em Jaboticabal-SP. Revista Brasileira de Fruticultura, Jaboticabal, v.22, p.208-212, 2000.

NISSEN, S.J.; SUTTER, E.G. Stability of IAA and IBA in nutrient medium to several tissue culture procedures. HortScience, Alexandria , v.25, p.800$802,1990$. 
PATI, P.K.; RATH, S.P.; SHARMA, M.; SOOD, A.; AHUJA, P.S. In vitro propagation of rose: a review. Biotechnology Advances, Oxford, v.24, p.94-114, 2006.

PIETROPAOLO, P.A.; REISCH, B.I. Micropropagation of 'Stanley' plum. HortScience, Alexandria, v.19, p.535-536, 1984.

POSPÍSILOVÁ, J.; HAISEL, D.; SYNKOVA, H.; CATSKY, J.; WILHELMOVÁ, N.; PLZÁKOVÁ, S.; PROCHÁRKOVÁ, D.; SRÁMEK, F. Photosynthetic pigments and gas exchange during ex vitro acclimation of tobacco plants as affected by $\mathrm{CO}_{2}$ supply and abscisic acid. Plant Cell, Tissue and Organ Culture, Dordrecht, v.61, p.125-133, 2000.

RADICE, S.; PERELMAN, P.E.; CASO, O.H. Propagación clonal de tres portainjertos del gênero Prunus para la Pampa Deprimida. FYTON, Buenos Aires, v.64, p.149-156, 1999.

RADMANN, E.B.; FACHINELLO, J.C.; PETERS, J.A. Efeito de auxinas e condições de cultivo no enraizamento in vitro de porta-enxertos de macieira 'M-9'. Revista Brasileira de Fruticultura, Jaboticabal, v.24, p.624-628, 2002.

RADMANN, E.B.; GONÇALVES, E.D.; FORTES, G.R. de L. Concentrações de ácido indolbutírico no enraizamento de amoreira-preta. Revista Brasileira de Fruticultura, Jaboticabal, v.25, p.124-126, 2003.

REETZ, E.R. Anuário brasileiro de fruticultura 2007/ERNA. Santa Cruz do Sul: Editora Gazeta, 2007. 236p.

REVERS, L.F.; MACHADO, C.A.E. Identificação varietal e genotipagem. Bento Gonçalves: Embrapa, 2005. (Comunicado Técnico, 64)
RESENDE, S.V.; LIMA-BRITO, A.; SANTANA, J.R.F.de. Influência do substrato e do enraizamento na aclimatização de Melocactus glaucescens Buining \& Brederoo propagados in vitro. Revista Ceres, Viçosa, MG, v.57, n.6, p.803-809, 2010.

ROCHA, P.S.G.; FACHINELLO, J.C.; SCHUCH, M.W.; BIANCHI, V.J.; CAMPOS, R.V. Efeito do ágar, vermiculita e sacarose no enraizamento do porta-enxerto cv. Mr. S. 2/5 in vitro. Revista Cientifica Rural, Bagé, v.11, n.1, p.54-59, 2006.

ROGALSKI, M.; MORAES, L.K.A. de; FELISBINO, C.; CRESTANI, L.; GUERRA, M.P.; SILVA, A.L. da. Aclimatização de porta-enxertos de Prunus sp. micropropagados. Revista Brasileira de Fruticultura, Jaboticabal, v.25, p.279-281, 2003a.

ROGALSKI, M.; MORAES, L.K.A. de; FELISBINO, C.; CRESTANI, L.; GUERRA, M.P.; SILVA, A.L. da. Enraizamento in vitro de porta-enxertos de Prunus. Revista Brasileira de Fruticultura, Jaboticabal, v.25, p.293-296, 2003b.

SOUZA, A.V.; PEREIRA, A.M.S. Enraizamento de plantas cultivadas in vitro. Revista Brasileira de Plantas Medicinais, Botucatu, v.9, p.103-117, 2007.

TONIETTO, A.; FACHINELLO, J.C.; KERSTEN, E. Enraizamento e sobrevivência de mudas de ameixeira produzidas por estaquia. Revista Científica Rural, Bagé, v.10, n.2, p.36-42, 2005.

VIGANÓ, R.C.; BIANCHI, V.J.; ROCHA, P.S.G. da; SCHUCH, M.W.; FACHINELLO, J.C. Enraizamento in vitro do porta-enxerto de Prunus cv. Mr. S. 1/8: concentrações de IBA em meio de cultura acrescido de ágar ou vermiculita. Bioscience Journal, Uberlândia, v.23, n.3, p.60-65, 2007. 